\title{
New motile anaerobic bacteria growing by succinate decarboxylation to propionate
}

\author{
Karin Denger and Bernhard Schink \\ Lehrstuhl Mikrobiologie I, Eberhard-Karls-Unıversitäı, Auf der Morgenstelle 28, W-7400 Tübingen, Federal Republic of Germany
}

Received April 25, 1990/Accepted August 14, 1990

\begin{abstract}
Three strains of new anaerobic, gram-negative bacteria which grew with succinate as sole source of carbon and energy were isolated from anoxic marine and freshwater mud samples. Cells of the three strains were small, non-spore-forming, motile rods or spirilla. The guanine-plus-cytosine content of the DNA of strain US2 was $52.6 \pm 1.0 \mathrm{~mol} \%$, of strain Ft $63.5 \pm 1.4 \mathrm{~mol} \%$, and of strain Ft1 $62.6 \pm 1.0 \mathrm{~mol} \%$. Succinate was fermented stoichiometrically to propionate and carbon dioxide. The growth yields were $1.2-2.6 \mathrm{~g}$ dry cell mass per mol succinate degraded. Strains US2 and Ft 2 required $0.05 \% \mathrm{w} / \mathrm{v}$ yeast extract in addition to succinate for reproducible growth. Optimal growth occurred at $30^{\circ}-37^{\circ} \mathrm{C}$ and pH 6.8-8.0. Addition of acetate as cosubstrate did not stimulate growth with any strain. Strain Ft2 grew only under strictly anaerobic conditions, whereas strains US2 and $\mathrm{Ft} 1$ tolerated oxygen up to $20 \%$ in the headspace. Strains US2 and Ft2 grew only with succinate. Strain Ft1 also converted fumarate, aspartate, and sugars to propionate and acetate. This strain also oxidized propionate with nitrate to acetate. Very low amounts of a $c$-type cytochrome were detected in propionate plus nitrate- or glucose-grown cells of this strain $(0.4 \mu \mathrm{g} \times \mathrm{g}$ protein $^{-1}$ ). Moderate activities of avidin-sensitive methylmalonyl-CoA decarboxylase were found in cellfree extracts of all strains.
\end{abstract}

Key words: Succinate fermentation - Decarboxylation energy $-\mathrm{Na}^{+}$bioenergetics - Flagellar motors - Propionate oxidation - Methylmalonyl-CoA

Succinate is an important end product of anaerobic fermentations (Gottschalk and Andreesen 1979). Aerobically it is oxidized completely to carbon dioxide in the citric acid cycle. Many sulfate-reducing bacteria can oxidize succinate (Widdel 1988), and phototrophic purple bacteria assimilate succinate as cell carbon source (Biebl

Offprint requests to $\mathrm{K}$. Denger and Pfennig 1981). Some rumen bacteria such as Selenomonas ruminantium (Scheifinger and Wolin 1973) or Veillonella alcalescens (Yousten and Delwiche 1961) have been shown to decarboxylate succinate to propionate in a reaction not linked to growth. A strictly anaerobic bacterium, Propionigenium modestum, was isolated which can grow on the basis of this decarboxylation reaction (Schink and Pfennig 1982b). The reaction sequence of succinate degradation includes succinyl-CoA, methylmalonly-CoA, and propionyl-CoA (Hilpert et al. 1984). The small free energy change of the decarboxylation reaction $\left(\Delta \mathrm{G}_{\mathrm{o}}{ }^{\prime}=-20.5 \mathrm{~kJ} / \mathrm{mol}\right.$ succinate; Thauer et al. 1977) is converted into a sodium ion gradient which drives synthesis via a sodium ion dependent ATPase (Hilpert et al, 1984). Propionigenium modestum is a saltwater isolate and requires at least $10 \mathrm{~g}$ sodium chloride per liter medium for growth. It was the aim of the present study to look for new bacterial strains which ferment succinate under different conditions. In the present paper three new strains conserving energy from succinate decarboxylation are described.

\section{Materials and methods}

\section{Sources of organisms}

The new strains were isolated from enrichment cultures inoculated with mud samples from the following sources: Strain US2 from marine sediment of the Sippewissett salt marshes, close to Woods Hole, MA, USA; strains Ft2 and Ft from digested anaerobic sludge of a municipal sewage plant at Marburg-Cappel, FRG.

Propionibacterium freudenreichii ssp. shermanii (DSM 20270) and Escherichia coli K12 (DSM 498) were obtained from the Deutsche Sammlung von Mikroorganismen, Braunschweig, FRG.

\section{Media and growth conditions}

All procedures for cultivation and isolation were as previously described (Widdel and Pfennig 1981; Schink and Pfennig 1982a: Schink 1984). The mineral salts medium for isolation and further cultivation was carbonate-buffered $(30 \mathrm{mM})$ and sulfide-reduced 
(1 $\mathrm{mM}$ ), and contained $1 \mathrm{ml}$ of selenite-tungstate solution and $1 \mathrm{ml}$ of trace element solution SL 10 (Widdel et al. 1983) per liter, as well as $0.5 \mathrm{ml}$ per liter of 7-vitamins solution (Widdel and Pfennig 1981). The $\mathrm{pH}$ was adjusted to $7.1-7.3$. Growth experiments were carried out either in $22 \mathrm{ml}$ screw-cap tubes completely filled with medium, or in $120 \mathrm{ml}$ serum bottles filled with $60 \mathrm{ml}$ medium under an atmosphere of $\mathrm{N}_{2} / \mathrm{CO}_{2}(90 \% / 10 \%)$. All growth experiments were carried out at least in duplicates at $30^{\circ} \mathrm{C}$ unless stated otherwise

\section{Isolation and characterization}

Pure cultures were obtained by repeated application of the agar shake culture method (Pfennig 1978). Purity was checked microscopically and also by growth tests in complex medium (AC-medium. Difco-Laboratories, Detroit, MI, USA). Growth was followed by measuring turbidity at $400 \mathrm{~nm}$ wavelength with a Spectronic 20 Spectrophotometer (Milton Roy, Rochester, NY, USA) or in $1-\mathrm{ml}$ cuvettes in a spectrophotometer model $100-40$ (Hitachi, Tokyo, Japan). Gram staining was carried out according to Bartholomew (1962) with Propionibacterium freudenreichii and Escherichia coli as controls. The $\mathrm{KOH}$ test according to Gregersen (1978) was applied in addition. Spore formation was checked after growth in medium with $20 \%$ soil extract, $1 \%$ Trypton, $0.1 \%$ Xylose. and $0.5 \% \quad \mathrm{MnSO}_{4}$ according to Hollaus and Sleytr (1972). Cytochromes were assayed in cell-free extracts as well as in membrane preparations obtained by ultracentrifugation $(1 \mathrm{~h}$ at $150000 \mathrm{~g}$ ). Samples were subjected to difference spectroscopy (dithionite-reduced minus air-oxidized) in an Uvikon 860 spectrophotometer (Kontron, Zurich, Switzerland). The DNA base composition was determined by thermal denaturation according to De Ley et al. (1970) after extraction described by Marmur (1961). Escherichia coli strain $\mathrm{K} 12$ was taken as reference.

\section{Chemical analyses}

Acetate and propionate were assayed by gas chromatography with a Carlo Erba 6000 gas chromatograph (Milano, Italy) as described (Platen and Schink 1987). Succinate was determined as dimethylester by capillary gas chromatography (Dehning and Schink 1989). $\mathrm{H}_{2}$ was determined with a thermal conductivity detector and a steel column ( $2 \mathrm{~m} \times 4 \mathrm{~mm})$ packed with $60 / 80$ mesh molecular sieve ( 5 A, Serva, Heidelberg, FRG), detector temperature $130^{\circ} \mathrm{C}$, column temperature $50^{\circ} \mathrm{C}$, carrier gas nitrogen, $78 \mathrm{ml} / \mathrm{min}$.

Formation of sulfide from sulfate or sulfur was determined half-quantitatively (Cord-R uwisch 1985). Formation of nitrite from nitrate was assayed by azo dye formation with sulfanilic acid and o-napthylamine (Procházková 1959).

\section{Enzyme assays}

Methylmalonyl-CoA decarboxylase activity in crude cell extracts was assayed photometrically at $25^{\circ} \mathrm{C}$ (modified after Hilpert and Dimroth 1983). The cuvette contained in $1 \mathrm{ml}: 100 \mathrm{mM}$ potassium phosphate buffer, $\mathrm{pH} 7.0,20 \mathrm{mM} \mathrm{NaCl}, 5 \mathrm{U}$ phosphotransacetylase, and $0.1 \mathrm{mM}$ methylmalonyl-CoA. Control experiments were carried out with crude cell extract preincubated for $15 \mathrm{~min}$ at room temperature with $0.1 \mathrm{mg}$ avidin or with $0.1 \mathrm{mg}$ avidin pretreated with $0.1 \mathrm{mg}$ biotin.

Protein in crude cell extracts was determined with $\mathrm{CuSO}_{4}$ in alkaline solution (Zamenhoff 1957).

\section{Chemicals}

All chemicals were of reagent grade quality and obtained from Fluka, Neu-Ulm; Merck, Darmstadt; Sigma, München, and
Boehringer, Mannheim. FRG. All ionophores were from Sigma, München. Gases were obtained from Messer-Griesheim, Darmstadt, FRG.

\section{Results}

\section{Enrichment and isolation}

Enrichment cultures with freshwater and saltwater me$\operatorname{dium}(50 \mathrm{ml}$ ) containing $20 \mathrm{mM}$ di-sodium succinate with or without $5 \mathrm{mM}$ sodium acetate were inoculated with $5 \mathrm{ml}$ of anoxic mud samples. Turbidity developed within $1-2$ weeks. In subcultures with the same substrate, turbidity developed within $2-5$ days and the cell population got more and more uniform. After 5-6 transfers, the fastest growing cultures were diluted in two subsequent agar shake series each. Three morphologically different pure cultures growing with succinate as substrate were isolated and further characterized. Strain US2 was isolated in saltwater medium whereas strains Ft2 and Ft1 were freshwater isolates. Two strains (US2 and Ft2) required $0.05 \%$ yeast extract for growth.

\section{Morphology and cytological properties}

Cells of strain US2 were small, slightly curved rods, $0.2-$ $0.3 \times 2-3 \mu \mathrm{m}$ in size (Fig. 1 a). Cells of strain Ft2 were small spirilla, $0.2 \mu \mathrm{m} \times 2-10 \mu \mathrm{m}$ (Fig. $1 \mathrm{~b}$ ). Cells of strain Ftl were short, slightly curved rods, $0.5 \times 2-3 \mu \mathrm{m}$ in size, often occurring in pairs (Fig. 1c). All strains were very motile in fresh cultures. All strains stained gramnegative and the $\mathrm{KOH}$ test showed slime formation typical of gram-negative bacteria. Spore formation was never observed, neither in defined medium nor in a special sporulation medium. The guanine-plus-cytosine content of the DNA of strain US2 was $52.6 \pm 1 \mathrm{~mol} \%$, of strain $63.5 \pm 1.4 \mathrm{~mol} \%$, and of strain $\mathrm{Ft1} 62.6 \pm 1 \mathrm{~mol} \%$.

Very low amounts of a cytochrome were detected only with strain Ft1 in crude cell extracts as well as in the cytoplasmic fraction of propionate plus nitrate- or glucose-grown cells. From the absorption bands at 552 and $420 \mathrm{~nm}$, it was identified as a $c$-type cytochrome. Assuming a molecular weight of 12000 and an extinction coefficient for the $\alpha$-peak of $19.0 \mathrm{mM}^{-1} \mathrm{~cm}^{-1}$ (Chance and Williams 1955), a cytochrome $c$ content of $0.4 \mu \mathrm{g}$ per g protein was calculated.

\section{Growth conditions and physiology}

All strains fermented succinate stoichiometrically to propionate (Table 1) and carbon dioxide (not determined). The growth rates with $20 \mathrm{mM}$ succinate were $0.045 \mathrm{~h}^{-1}$ $\left(\mathrm{t}_{\mathrm{d}}=15 \mathrm{~h}\right)$ with strain US2, $0.025 \mathrm{~h}^{-1}\left(\mathrm{t}_{\mathrm{d}}=28 \mathrm{~h}\right)$ with strain Ft2, and $0.05 \mathrm{~h}^{-1}\left(\mathrm{t}_{\mathrm{d}}=14 \mathrm{~h}\right)$ with strain Ft1. Optimal growth occurred at $30-37^{\circ} \mathrm{C}$ and $\mathrm{pH} 6.8-8.0$. The temperature limits were 24 and $45^{\circ} \mathrm{C}$, the $\mathrm{pH}$ range was 6.3-8.4. Phosphate concentrations up to $50 \mathrm{mM}$ did not influence growth. Optimal growth occurred with succi- 

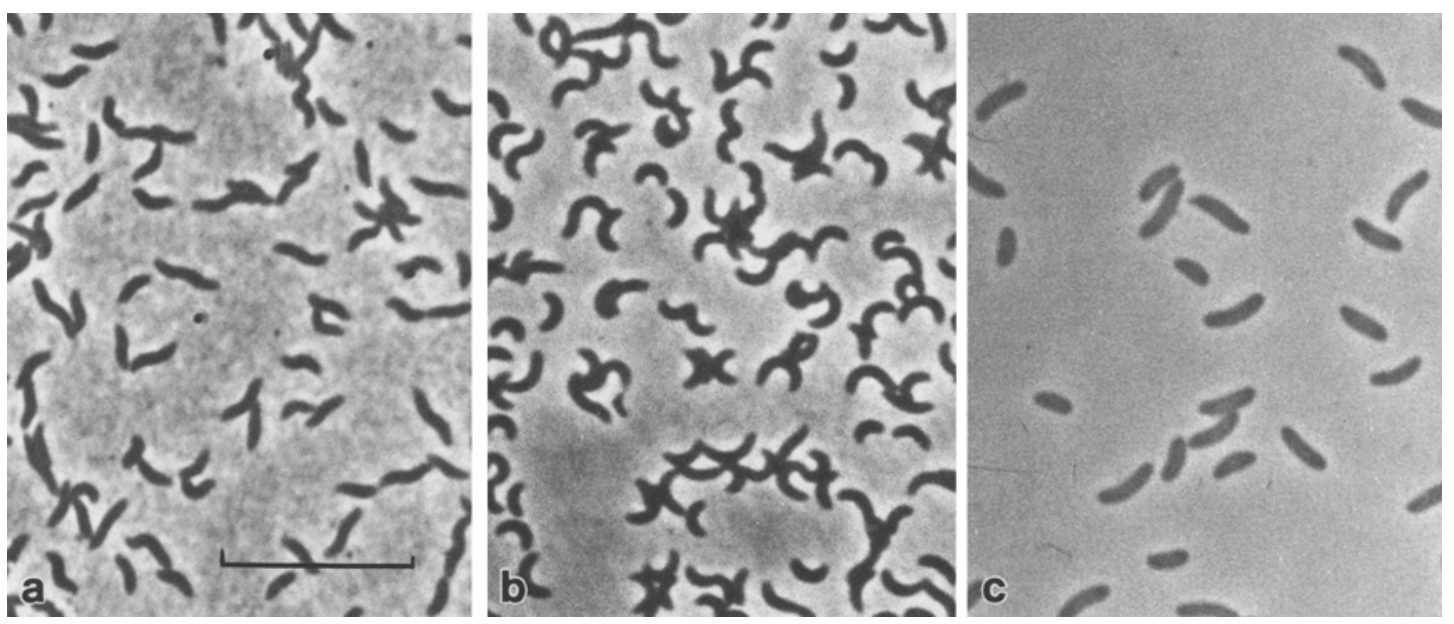

Fig. 1 a-c. Phase contrast photomicrographs of strain US2, Ft2 and Ft1. Bar equals $10 \mu \mathrm{m}$ for all panels

Table 1. Fermentation stoichiometries and growth yields of the strains US2, Ft2 and Ft1 with succinate as substrate

\begin{tabular}{|c|c|c|c|c|c|c|}
\hline Strain & $\begin{array}{l}\text { Sub- } \\
\text { strate } \\
\text { degra- } \\
\text { ded }^{a} \\
{[\mu \mathrm{mol}]}\end{array}$ & $\begin{array}{l}\text { Cell } \\
\text { dry } \\
\text { mass } \\
\text { formed }^{b} \\
{[\mathrm{mg}]}\end{array}$ & $\begin{array}{l}\text { Sub- } \\
\text { strate } \\
\text { assimi- } \\
\text { lated }^{c} \\
{[\mu \mathrm{mol}]}\end{array}$ & $\begin{array}{l}\text { Pro- } \\
\text { pionate } \\
\text { formed }\end{array}$ & $\begin{array}{l}\text { Elec- } \\
\text { tron } \\
\text { reco- } \\
\text { very } \\
{[\%]}\end{array}$ & $\begin{array}{l}\text { Molar } \\
\text { growth } \\
\text { yield } \\
{[\mathrm{g} / \mathrm{mol}]}\end{array}$ \\
\hline US2 & 1000 & 1.23 & 14.5 & 1010 & 102 & 1.2 \\
\hline $\mathrm{Ft} 2$ & 795 & 2.04 & 24.1 & 745 & 97 & 2.6 \\
\hline Ft1 & 925 & 2.25 & 26.6 & 890 & 99 & 2.4 \\
\hline
\end{tabular}

Experiments were carried out in 120-ml serum bottles filled half with medium under $\mathrm{N}_{2} / \mathrm{CO}_{2}(90 \% / 10 \%)$ gas mixture and sealed. Strains US2 and $\mathrm{Ft} 2$ required $0.05 \%$ yeast extract in addition to succinate for growth

a Substrate degraded was calculated from the difference of substrate concentration at the beginning and the end of the experiment

b Cell dry mass was calculated via cell turbidity using the conversion factors $0.1 \mathrm{OD}_{400}=49 \mathrm{mg}$ dry mass per liter (US2), $0.1 \mathrm{OD}_{400}=$ $37 \mathrm{mg}$ dry mass per liter (Ft2), $0.1 \mathrm{OD}_{400}=30 \mathrm{mg}$ dry mass per liter (Ft1), which were obtained by direct gravimetric determination in $500 \mathrm{ml}$ cultures grown with succinate

c Assimilation of substrates into cell material was calculated using the formula $\left\langle\mathrm{C}_{4} \mathrm{H}_{7} \mathrm{O}_{3}\right\rangle$ for cell material, and the following assimilation equation for succinate: 17 succinate $^{2-}+32 \mathrm{H}_{2} \mathrm{O} \rightarrow 14$ $\left\langle\mathrm{C}_{4} \mathrm{H}_{7} \mathrm{O}_{3}\right\rangle+12 \mathrm{HCO}_{3}^{-}+22 \mathrm{OH}^{-}$; thus, $11.8 \mu \mathrm{mol}$ succinate was degraded to form $1 \mathrm{mg}$ cell material

nate at concentrations of 20 to $40 \mathrm{mM}$. The saltwater isolate US2 grew in medium containing $0.1-2.0 \% \mathrm{NaCl}$ $(\mathrm{w} / \mathrm{v})$ and $0.015-0.3 \% \mathrm{MgCl}_{2} \times 6 \mathrm{H}_{2} \mathrm{O}(\mathrm{w} / \mathrm{v})$, respectively, but growth ceased after 3-4 transfers in freshwater medium (containing $0.1 \% \mathrm{NaCl}$ and $0.015 \% \mathrm{MgCl}_{2}$ ). The freshwater isolates $\mathrm{Ft} 2$ and $\mathrm{Ft} 1$ tolerated $\mathrm{NaCl}$ up to $1 \%(\mathrm{w} / \mathrm{v})$ and $\mathrm{MgCl}_{2}$ up to $0.15 \%(\mathrm{w} / \mathrm{v})$.

Strain Ft2 grew only under strictly anaerobic conditions, whereas strains US2 and Ft1 tolerated traces of oxygen as visualized in oxygen gradient tube cultures. Growth of strain Ft1 was possible even under air in a phosphate-buffered medium with succinate as substrate.

Addition of acetate as cosubstrate did not stimulate growth with any strain.
Strains US2 and Ft2 were specialized for succinate fermentation only and did not ferment any other organic substrates including other dicarboxylic acids, sugars, lactate, pyruvate, glycerol, ethanol, ethylene glycol, acetoin, and 2,3-butandiol. $\mathrm{H}_{2}$ or formate was not oxidized, nitrate, sulfate, thiosulfate, sulfite, or sulfur was not reduced.

Unlike these strains, strain Ft1 exhibited a broader metabolic versatility. It fermented fumarate, aspartate, and sugars to propionate and acetate (Table 2). Weak growth occurred with malate, pyruvate, or glycerol as substrates.

The amount of fermentation products agreed with complete conversion of the substrates according to the following equations:

$$
\begin{aligned}
\text { succinate }^{2-}+\mathrm{H}_{2} \mathrm{O} \rightarrow & \text { propionate }+\mathrm{HCO}_{3}^{-} \\
3 \text { fumarate }^{2-}+6 \mathrm{H}_{2} \mathrm{O} \rightarrow & 2 \mathrm{G}_{0}^{\prime}=20.5 \mathrm{~kJ} / \mathrm{mol}_{\text {succinate }} \\
& +4 \mathrm{HCO}_{3}^{-}+\mathrm{H}^{+} \\
& \Delta \mathrm{G}_{0}^{\prime}=-81.1 \mathrm{~kJ} / \mathrm{mol} \\
& \text { umarate } \\
3 \text { aspartate }^{-}+6 \mathrm{H}_{2} \mathrm{O} \rightarrow & 2 \text { propionate } \\
& +4 \mathrm{HCO}_{3}^{-}+\text {acetate }^{-} \\
& +3 \mathrm{HN}_{4}^{+}+\mathrm{H}^{+} \\
& \Delta \mathrm{G}_{0}^{\prime}=-51.3 \mathrm{~kJ} / \mathrm{mol} \\
& \text { aspartate } \\
\rightarrow & 4 \text { propionate }^{-}+2 \text { acetate }^{-} \\
& +2 \mathrm{HCO}_{3}^{-}+8 \mathrm{H}^{+} \\
& \Delta \mathrm{G}_{0}^{\prime}=-308.1 \mathrm{~kJ} / \mathrm{mol} \\
& \text { hexose } \\
\rightarrow & 4 \text { propionate }^{-}+3 \text { acetate } \\
& +2 \mathrm{HCO}_{3}^{-}+9 \mathrm{H}^{+} \\
& \Delta \mathrm{G}_{0}^{\prime}=-264.0 \mathrm{~kJ} / \mathrm{mol} \text { pen- } \\
& \text { tose. }
\end{aligned}
$$

Addition of hemin at concentrations up to $100 \mu \mathrm{g} / \mathrm{l} \mathrm{did}$ not enhance growth yields with fumarate or aspartate. In growth experiments with $20 \mathrm{mM}$ succinate plus $2-8 \mathrm{mM}$ sodium nitrate, growth of strain Ft1 was enhanced by nitrate (Fig. 2). Nitrate was reduced stoichiometrically to nitrite. Figure 3 shows that also propionate could be oxidized to acetate while nitrate was reduced to nitrite. 
Table 2. Fermentation stoichiometries and growth yields of strain Ft1

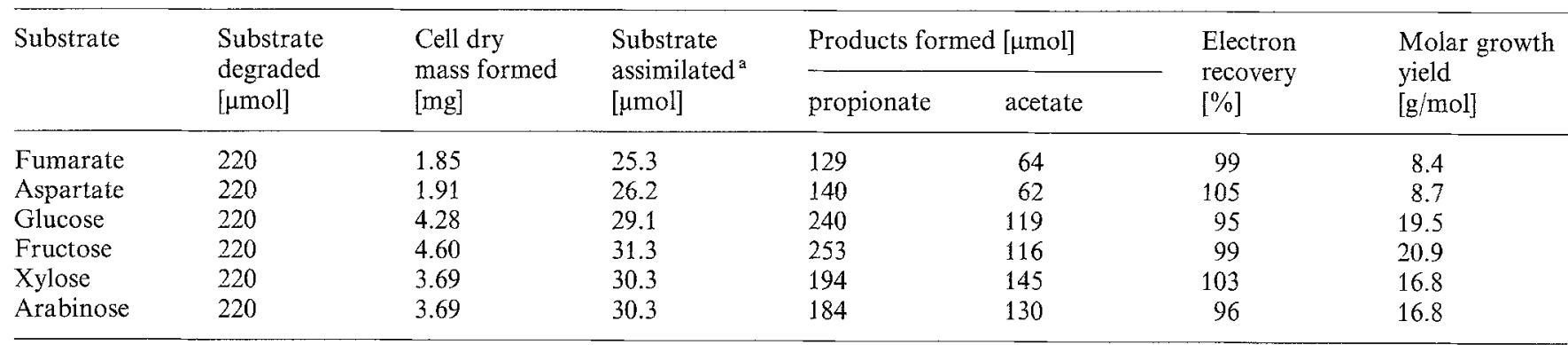

Experiments were carried out in $22-\mathrm{ml}$ screw-cap tubes filled completely with medium. Calculations of substrate degradation and cell dry mass formation as in Table 1

a The following assimilation equations were used for calculation:

17 fumarate $^{2-}+42 \mathrm{H}_{2} \mathrm{O} \rightarrow 12\left\langle\mathrm{C}_{4} \mathrm{H}_{7} \mathrm{O}_{3}\right\rangle+20 \mathrm{HCO}_{3}^{-}+14 \mathrm{OH}^{-}$

17 aspartate ${ }^{-}+42 \mathrm{H}_{2} \mathrm{O} \rightarrow 12\left\langle\mathrm{C}_{4} \mathrm{H}_{7} \mathrm{O}_{3}\right\rangle+20 \mathrm{HCO}_{3}^{-}+14 \mathrm{H}_{2} \mathrm{O}+17 \mathrm{NH}_{3}+3 \mathrm{H}^{+}$

17 glucose/fructose $+6 \mathrm{OH}^{-} \rightarrow 24\left\langle\mathrm{C}_{4} \mathrm{H}_{7} \mathrm{O}_{3}\right\rangle+6 \mathrm{HCO}_{3}^{-}+18 \mathrm{H}_{2} \mathrm{O}$

17 xylose/arabinose $+5 \mathrm{OH}^{-} \rightarrow 20\left\langle\mathrm{C}_{4} \mathrm{H}_{7} \mathrm{O}_{3}\right\rangle+5 \mathrm{HCO}_{3}^{-}+15 \mathrm{H}_{2} \mathrm{O}$

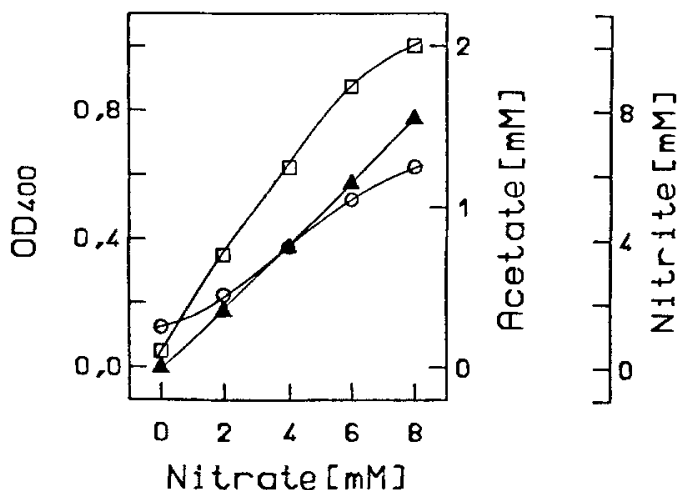

Fig. 2. Growth of strain Ft1 with $20 \mathrm{mM}$ succinate in the absence and presence of nitrate. Experiments were performed at $30^{\circ} \mathrm{C}$ in 22-ml screw-cap tubes. Symbols: $\bigcirc$ cell density, $\square$ acetate, $\boldsymbol{\Delta}$ nitrite. $\mathrm{OD}_{400}$ : optical density at $400 \mathrm{~nm}$

No other inorganic electron acceptor such as sulfate, thiosulfate, sulfite, or sulfur was reduced; neither $\mathrm{H}_{2}$ nor formate was oxidized by strain Ft1.

\section{Enzyme activities}

The key enzyme of succinate fermentation, methylmalonyl-CoA-decarboxylase, was assayed in Frenchpress cell extracts prepared from succinate-grown cells of all three strains. With strains US2 and Ft1, an activity of $0.33 \mathrm{U} / \mathrm{mg}$ protein was detected. If extracts were preincubated with avidin, only $25 \%$ of this activity was found. Avidin preincubated with biotin had no inhibitory effect. With strain $\mathrm{Ft} 2$, the methylmalonyl-CoA decarboxylase activity was $0.25 \mathrm{U} / \mathrm{mg}$ protein; this activity was only slightly inhibited by avidin.

\section{Discussion}

\section{Physiology}

Three new strains of succinate-fermenting bacteria were enriched and isolated from anoxic mud samples in the present study, showing that the ability of Propionigenium modestum to grow by decarboxylation of succinate to propionate was not an entirely unique phenomenon. Moreover, Sporomusa termitida and Sporomusa malonica were recently shown to grow by succinate decarboxylation as well (Breznak et al. 1988; Dehning et al. 1989), and also a thermophilic bacterium was isolated which can grow by succinate fermentation (Stams and Zehnder, pers. communication). Two of our new isolates as well as the Sporomusa species and the thermophilic isolate are freshwater organisms. Our medium contained only $0.1 \%$ $\mathrm{NaCl}(\mathrm{w} / \mathrm{v})$ and $0.015 \% \mathrm{MgCl}_{2} \times 6 \mathrm{H}_{2} \mathrm{O}(\mathrm{w} / \mathrm{v})$ showing that enhanced $\mathrm{NaCl}$ concentrations are not a necessary prerequisit of energy-conserving succinate fermentation. Molar growth yields of 1.2 to $2.6 \mathrm{~g}$ dry cell mass per mol succinate were calculated which are in the same range as the one determined for Propionigenium modestum $(2.4 \mathrm{~g}$ dry cell mass per mol succinate). These values correlate with the small free energy change of succinate decarboxylation $\left(\Delta \mathrm{G}_{0}{ }^{\prime}=20.6 \mathrm{~kJ} / \mathrm{mol}\right.$ succinate $)$. The yield differences observed may be due to different efficiencies of the energy-conserving systems involved in these new isolates.

Strains US2 and Ft2 were specialized on succinate fermentation only and did not grow with any other substrate tested. Unlike these two specialists, strain Ft1 showed a broader substrate spectrum and fermented also fumarate, aspartate, glucose, fructose, arabinose, and xylose to acetate and propionate. Weak growth occurred also with malate, pyruvate, and glycerol as substrates. Growth yields with fumarate and aspartate were higher than with succinate because additional energy can be conserved by the acetate-kinase reaction. However, these growth yields $(8.4-8.7 \mathrm{~g} / \mathrm{mol})$ are small if compared to those observed with Propionibacterium sp. with lactate $(10.2-12.9 \mathrm{~g} / \mathrm{mol}$; Stouthamer 1980), and this difference is even more expressed for growth with glucose (19.520.9 vs. $50-70 \mathrm{~g} / \mathrm{mol})$. These comparably low growth yields suggest that strain Ft1 does not conserve energy by electron transport in fumarate reduction, similar to other recently isolated gram-negative propionateforming bacteria (Schink and Pfennig 1982b; Schink et 


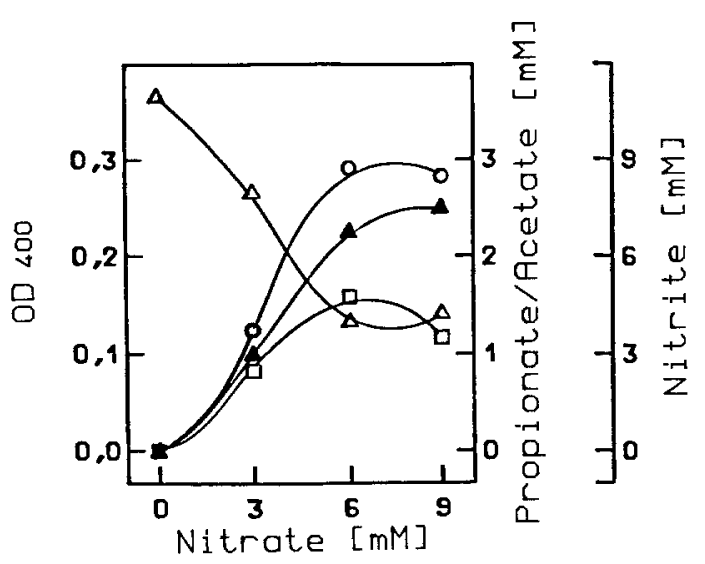

Fig. 3. Growth of strain Ft1 with $3 \mathrm{mM}$ propionate in the absence and presence of nitrate. Experimental conditions as described in Fig. 2. Symbols: $\bigcirc$ Cell density, $\triangle$ propionate, $\square$ acetate, $\Delta$ nitrite. $\mathrm{OD}_{400}$ : optical density at $400 \mathrm{~nm}$

al. 1987). This view is further supported by the obvious lack of significant amounts of a $b$-type cytochrome.

Growth of strain Ft1 with succinate was enhanced by addition of nitrate which was reduced stoichiometrically to nitrite. Also propionate, the end product of fermentative metabolism, could be oxidized to acetate and carbon dioxide while nitrate was reduced to nitrite. So far no nitrate-reducing, succinate-decarboxylating bacterium was described. Selenomonas ruminantium can reduce nitrate to nitrite (de Vries et al. 1973), and Veillonella alcalescens reduces nitrate to ammonia (Stouthamer 1980), but neither one can grow with succinate only.

In Propionigenium modestum, ATP synthesis during succinate fermentation is driven directly by a sodium ion gradient (Laubinger and Dimroth 1989) which is generated upon decarboxylation of methylmalonyl-CoA (Hilpert et al. 1984). With our new isolates, enzyme activities of the methylmalonlyl-CoA-decarboxylase could be detected which were inhibited by avidin indicating a biotin enzyme as described for Veillonella alcalescens (Hilpert and Dimroth 1983) and Propionigenium modestum. It remains to be elucidated whether also in our new isolates all energy-related membrane functions are sodium dependent. Preliminary experiments with ionophores and antiporter inhibitors (not shown) indicated that ATP synthesis and flagellar rotation are driven by a proton gradient.

\section{Taxonomy}

The three new succinate-fermenting strains differ in many respects from the first succinate-fermenting organism, Propionigenium modestum. They differ in morphology, motility, DNA base ratio, substrate spectrum and most likely in the energy coupling system. Morphologically, they resemble Campylobacter species which are as well gram-negative, motile, curved rods. Both strain Ft1 and Campylobacter species contain cytochromes and are able to reduce nitrate, but Campylobacter forms succinate and does not degrade it. Also the DNA base ratio of
Campylobacter with $29-38 \mathrm{~mol} \%$ is considerably lower than that of strain Ft1 and therefore an assignment to this genus is not possible. Sporomusa species ferment succinate, however, they form spores, which none of the new isolates does. There are similarities between the new isolates and the rumen bacterium Selenomonas ruminantium with respect to gram-staining reaction, DNA base ratio, and degradation of succinate, but Selenomonas ruminantium cannot grow with succinate. The taxonomic assignment of these new isolates will be treated in a later communication. Strains US2 and Ft1 were deposited with the Deutsche Sammlung von Mikroorganismen, Braunschweig, under the numbers 5848 and 5849 , respectively.

Acknowledgements. The authors thank Elke Steppohn and Fitnat Yildiz for help in enrichment and isolation of the new strains, and Rolf Thauer and Peter Dimroth for helpful discussions concerning the energetics of our new isolates.

\section{References}

Bartholomew JM (1962) Variables influencing results, and the precise definition of steps in Gram staining as a means of standardizing the results obtained. Stan Technol 37:139-155

Biebl H, Pfennig N (1981) Isolation of members of the family Rhodospirillaceae. In: Starr MP, Stolp H, Trüper HG, Balows A, Schlegel HG (eds) The prokaryotes. a handbook on habitats, isolation, and identification of bacteria. Springer. Berlin Heidelberg New York, pp 267-273

Breznak JM, Switzer JM, Seitz HJ (1988) Sporomusa termitida sp. nov., an $\mathrm{H}_{2} / \mathrm{CO}_{2}$-utilizing acetogen isolated from termites. Arch Microbiol 150:282-288

Chance B, Williams GR (1955) Respiratory enzymes in oxidative phosphorylation. II. Difference spectra. J Biol Chem 217:395 -407

Cord-Ruwisch R (1985) A quick method for the determination of dissolved and precipitated sulfides in cultures of sulfate-reducing bacteria. J Microbiol Methods 4:33-36

Dehning I, Schink B (1989) Malonomonas rubra gen. nov. sp. nov., a microaerotolerant anaerobic bacterium growing by decarboxylation of malonate. Arch Microbiol 151:427-433

Dehning I, Stieb M. Schink B (1989) Sporomusa malonica sp. nov., a homoacetogenic bacterium growing by decarboxylation of malonate or succinate. Arch Microbiol 151:421-426

De Ley J, Cattoir H, Reynaerts A (1970) The quantitatıve measurement of DNA hybridization from renaturation rates. Eur $\mathrm{J}$ Biochem 12:133-143

De Vries W, van Wijck-Kapteyn WMC, Oosterhuis SKH (1973) The presence and function of cytochromes in Selenomonas ruminantium, Anaerovibrio lipolytica and Veillonella alcalescens. I Gen Microbiol 81:69-78

Gottschalk G, Andreesen JR (1979) Energy metabolism in anaerobes. In: Quayle JR (ed) International review of biochemistry (Microbial biochemistry, vol. 21). University Park Press, Baltimore, pp $85-115$

Gregersen T (1978) Rapid method for distincuon of gram-negative from gram-positiv bacteria. Eur J Appl Microbiol Biotechnol $5: 123-127$

Hilpert W, Dimroth P (1983) Purification and characterization of a new sodium-transport decarboxylase. Eur J Biochem 132: $579-$ 587

Hilpert W. Schink B, Dimroth P (1984) Life by a new decarboxylation-dependent energy conservation mechanism with $\mathrm{Na}^{+}$as coupling ion. EMBO J 3:1665-1670

Hollaus F, Sleytr V (1972) On the taxonomy and fine structure of some hyperthermophilic saccharolytic clostridia. Arch Mikrobiol 86:129-146 
Laubinger W, Dimroth P (1989) The sodium ion translocating adenosinetriphosphatase of Propionigenium modestum pumps protons at low sodium ion concentrations. Biochemistry 28:7194-7198

Marmur $J$ (1961) A procedure for the isolation of deoxyribonuclerc acid from microorganisms. J Mol Biol 3:208-218

Pfennig N (1978) Rhodocyclus purpureus gen. nov. sp. nov., a ringshaped, vitamin $\mathrm{B}_{12}$-requiring member of the family Rhodospirillaceae. Int J Syst Bacteriol 28:283-288

Platen H, Schink B (1987) Methanogenic degradation of acetone by an enrichement culture. Arch Microbiol 149:136-141

Procházková L (1959) Bestimmung der Nitrate im Wasser. Z Anal Chem 167:254-260

Scheifinger CC, Wollin MJ (1973) Propionate formation from cellulose and soluble sugars by combined cultures of Bacteroides succinogenes and Selenomonas ruminantium. Appl Microbiol $26: 789-795$

Schink B (1984) Fermentation of 2,3-butanediol by Pelobacter carbmollcus sp. nov, and Pelobacter propionicus sp. nov., and evidence for propionate formation from $\mathrm{C}_{2}$ compounds. Arch Microbiol 137:33-41

Schink B, Pfennig N (1982a) Fermentation of trihydroxybenzenes by Pelobacter acidigallici gen. nov. sp. nov., a new strictly anaerobic, non-sporeforming bacterium. Arch Microbiol 133.195201

Schink B, Pfennig N (1982b) Propionigenium modestum gen. nov., sp. nov., a new strictly anaerobic nonsporing bacterium growing on succinate. Arch Microbiol 133:209-216

Schink B, Kremer DR, Hansen TA (1987) Pathway of propionate formation from ethanol in Pelobacter propionicus. Arch Microbiol 147:321-327
Stouthamer AH (1980) Electron transport linked phosphorylation in anaerobes. In: Gottschalk G, Werner H, Pfennig N (eds) Anaerobes and anaerobic infections. Gustav Fischer, Stuttgart New York, pp 17-29

Thauer RK, Jungermann K, Decker K (1977) Energy conservation of chemotrophic anaerobic bacteria. Bacteriol Rev 41:100180

Widdel F (1988) Microbiology and ecology of sulfate- and sulfurreducing bacteria. In: Zehnder AJB (ed) Biology of anaerobic microorganisms. J W1ley \& Sons, New York, pp 469-585

Widdel F, Pfennig N (1981) Studies on dissimilatory sulfate-reducing bacteria that decompose fatty acids. I. Isolation of new sulfate reducing bacteria enriched with acetate from saline environements. Description of Desulfobacter postgatei gen. nov., sp. nov Arch Microbiol 129:395-400

Widdel F, Kohring GW, Mayer F (1983) Studies on dissimilatory sulfate-reducing bacteria that decompose fatty acids. III. Characterization of the filamentous gliding Desulfonema limicola gen. nov., sp. nov., and Desulfonema magnum sp. nov. Arch Microbiol 134:286-294

Yousten AA, Delwiche EA (1961) Biotin and vitamin $B_{12}$ coenzymes in succinate decarboxylation by Propionibacterium pentosaceum and Veillonella alcalescens. Bacteriol Proc 61:175

Zamenhoff S (1957) Preparation and assay of deoxyribonucleic acid from animal tissue. In: Colowick SP, Kaplan NO (eds) Methods of enzymology, vol 3. Academic Press, New York, pp 696-704 